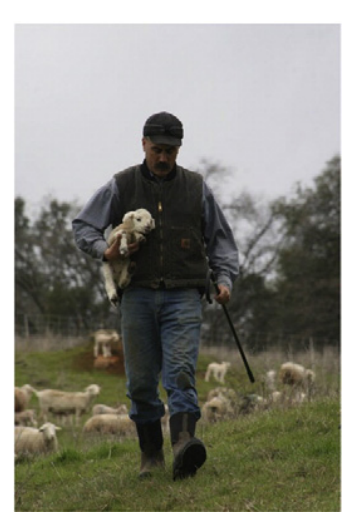

By Dan Macon

\title{
Essays From a Foothill Agrarian
}

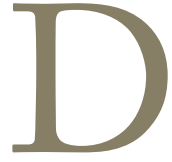

an Macon and his family own Flying Mule Farm, a small commercial sheep operation in the foothills near Auburn, CA. He is the herdsman at the University of California Sierra Foothill Research and Extension Center in Browns Valley and past president of the Society for Range Management California-Pacific Section. Dan regularly blogs his thoughts about sustainable agriculture and forestry in the Sierra Nevada foothills. ${ }^{i}$ Here we share three of his recent essays.

\section{Disappearing}

Originally posted July 15, 2015

In my Sunday paper, an article from The New York Times appeared entitled "China Fences in Its Nomads, and an Ancient Life Withers." The article described the efforts by the Chinese government to relocate nomadic herders in China's western provinces, based (in part) on the official position that "grazing harms grasslands." Does this sound familiar? Later in the day on Sunday, I went fishing in the upper reaches of the Yuba River watershed with my friend and sheep shearer Derrick Adamache. The stretch of the Yuba that we fished, which is managed by the US Forest Service, was once part of a grazing allotment. Based on the decadent grasses and overgrown brush, I'd say that this part of my own backyard has been subjected to the same official (and popular) viewpoint.

Grazing livestock is an ancient art, as the Times article suggests, and admittedly one that can cause problems if improperly managed. Unfortunately, native wisdom about this "art" is often discounted. Nomadic herders - and ranchers - often are seen as relics of the past, with little (if anything) to offer in the way of scientific understanding. According to the Times article:

"The idea that herders destroy the grasslands is just an excuse to displace people that the Chinese government thinks have a backward way of life," said Enghebatu Togochog, director of the Southern Mongolian Human Rights Information Center, based in Nerw York. "They promise good jobs and nice houses, but only later do the herders discover these things are untrue."

I think in some ways, governments find the self-sufficiency of nomads (and ranchers) to be threatening. The fact that people can exist-even thrive-with little or no government assistance or material wealth is threatening, especially to a totalitarian government like China's.

Similarly, I think that people without direct experience managing rangelands and grazing animals must have difficulty grasping the idea that grazing is regenerative to grasslands. In our disposable, consumption-based society, the idea that something is renewable (like grass) is a foreign concept.

Those of us in the ranching world sometimes fall prey to the same type of thinking. We talk about the genetic and management improvements that allow us to produce more beef or lamb on less land. To me, this misses the critical difference between rangeland and cultivated agriculture. I don't mean to diminish the importance of cultivated agriculture, but the beauty of rangeland agriculture is that I can produce meat, fiber, and milk on land that, by definition, cannot be cultivated. Most of the rangelands where I raise my sheep, for example, are too steep, too rocky, or too dry to grow a crop. Most of these lands cannot be irrigated. Despite these limitations, these lands grow wonderful grass, which my sheep "harvest" and turn into wool and lamb chops. Although efficiency is important, I believe that we

\footnotetext{
${ }^{i}$ Read more of Dan's essays at http://flyingmule.blogspot.com/.
} 
should embrace the fact that ours is a land-extensive enterprise. We need large, unbroken blocks of rangeland-for grazing, for wildlife habitat, for carbon sequestration, for open space, for watershed function! In other words, we shouldn't apologize for the fact that our ranching livelihoods keep large tracts of rangelands intact and undeveloped.

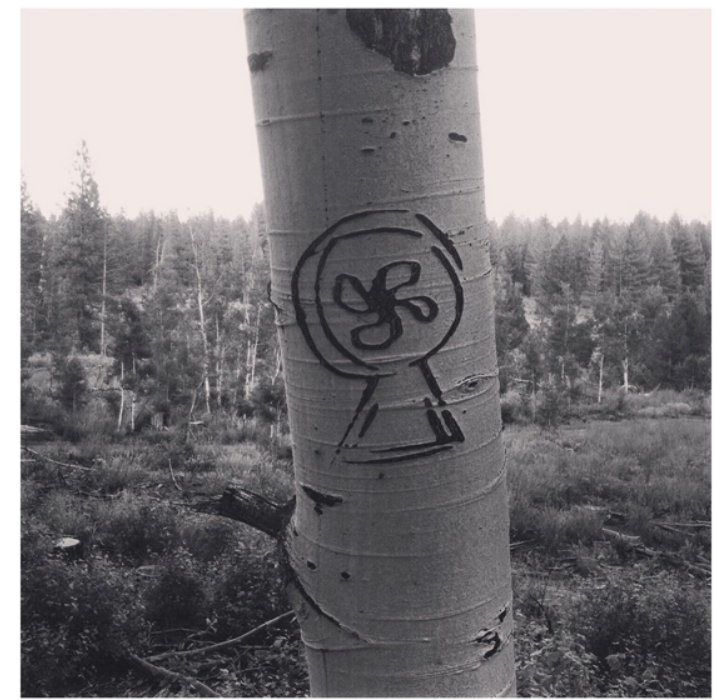

A "lauburu" or Basque cross arboglyph at Independence Lake in California.

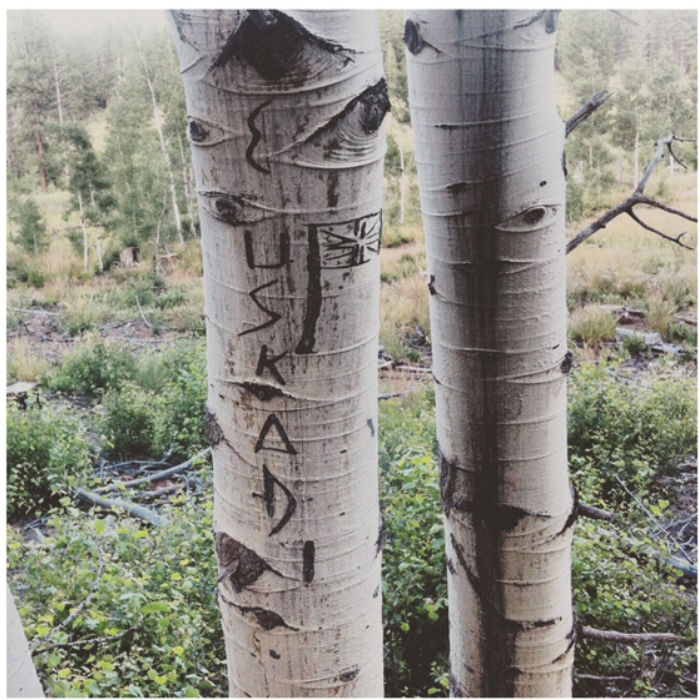

An arboglyph featuring a Basque flag.

As Derrick and I made our way back toward Truckee, we drove out to Independence Lake, which was recently acquired by the Nature Conservancy. On our way to the lake, we passed through an aspen grove that featured arboglyphs (tree carvings) created by a Basque sheepherder. The trees were on the edge of a sagebrush flat that to my shepherd's eye would have been an ideal bedding ground for sheep. But sheep are no longer present at Independence Lake-and neither are sheepherders. I couldn't help but wonder about the fate of the man who carved the Basque flag and the lauburu (Basque cross) on the aspens we photographed. I also wondered about the fate of the Chinese herders whose lives have been "improved" by the government. As the Times article reported:

\section{Like hundreds of thousands of pastoralists across China who have been relocated into bleak townships over the past decade, he is jobless, deeply indebted and dependent on shrinking government subsidies to buy the milk, meat and wool he once obtained from bis flocks. ${ }^{1}$}

An essay like this should end with a call to action or on a positive note. This one doesn't. I find myself troubled and sad to think of my Chinese colleagues who have been forced to move to town. I find myself discouraged that grazing (and the livelihood and land uses it supports) in my own state faces similar (if less dramatic) challenges.

\section{Ranching and Nature \\ Originally posted August 11, 2015}

I just finished an interesting book titled $\boldsymbol{C o d}$, by Mark Kurlansky. The last paragraph in the book raises some interesting questions about our relationship with nature; questions that also have relevance to my own work as a rancher, I think:

There is a big difference between living in a society that hunts whales and living in one that vierws them. Nature is being reduced to precious demonstrations for entertainment and education, something far less natural than hunting. Are we headed for a world where nothing is left of nature but parks? Whales are mammals, and mammals do not lay a million eggs. We were forced to give up commercial hunting and to raise domestic mammals for meat, preserving the wild ones as best we could. ${ }^{2}$

Among the many things I like about my life as a pastoralist (i.e., someone whose work entails raising livestock on rangeland) is the fact that I get to work (as opposed to recreate) in and with nature. My day-to-day work-as herdsman at the Sierra Foothill Research and Extension Center and as shepherd in my own sheep operation-brings me into direct contact with the natural world.

As I grow older, I realize how unusual my way of making a living is in our modern society. Most of us come in to contact with nature as a break from our working lives. We recreate in nature, and as a consequence, I think we romanticize (and therefore, devalue) those livelihoods that still depend on nature. I fish for leisure; commercial fishing must be similarly leisurely. Alternatively, I ride a horse for pleasure; gathering cows on horseback can't be "real" work!

This perspective extends, I think, to our attitudes toward land and resource conservation. Over the past 10 to 15 years, ranch and farm land conservation has become a priority for many communities. We started to realize that productive agricultural land is vital to our nutritional well-being, as well as to the aesthetic quality of our "neighborhood." In many cases, however, we fail to recognize the human aspect of farm and ranch land. In other words, have we truly conserved a piece of farm land if nobody in our community knows how to farm it? Can ranch land exist without a rancher? 


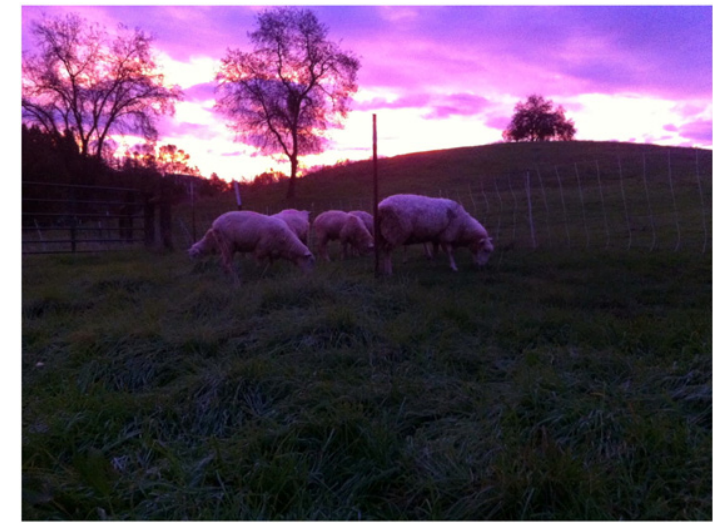

Ewes grazing at sunset near Auburn, California.

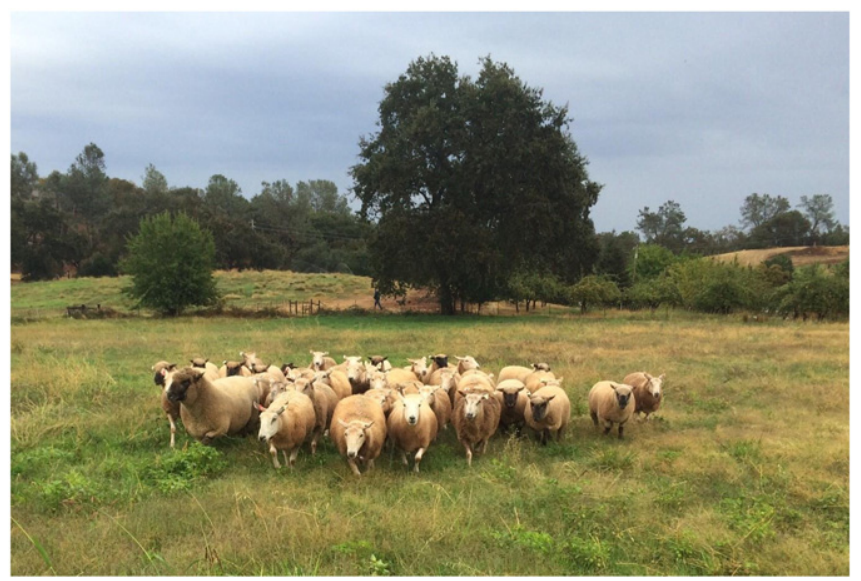

Kurlansky talks about this conundrum in Cod, quoting an official in the Gloucester (Massachusetts) Community Development Department:

You buy out a man whose father and grandfather were fishermen, and you are wiping out a bundred years of knowledge. A fisherman is a special person. He is a captain, a navigator, an engineer, a cutter, a gutter, an expert net mender, a market speculator. And he's a tourist attraction. People want to come to a town where there are men with cigars in their mouth and boots on their feet mending nets. We are going to lose all that. ${ }^{2}$

Ranching and farming involve similar "native" skills—and have a similar attraction to tourists. Although I think agricultural tourism has value, I worry that it diminishes the work essential to farming and ranching. Although agricultural skills provide a way to start a conversation about farming or ranching, the ability to rope a calf, or work a stock dog, or bring in a crop, is far more important than its entertainment value.

\section{Stockmanship Notes: Belief, Attitude, and Punching a Clock}

Originally posted July 22, 2015

Bud Williams, who taught many people how to use low-stress stockmanship, said that this approach to working livestock requires "belief and the will to do it." In other words, low-stress stock handling requires a commitment to learning through experience. As I've written before, learning to work livestock with low-stress techniques is a learning process for me. The key, for me, is that I believe in it. When something doesn't work, I don't abandon my belief in the approach; rather, I think about what I could have done differently. Recently, however, I've come to believe that time is a critical component of this approach. Part of this is the recognition that sometimes I need to "move slowly to work quickly" - working cattle or sheep calmly and deliberately makes the overall effort go more quickly. I've also realized that my efforts to work effectively with my dogs, horses, and mule require me to take time, while we're working, to improve our partnership.

Don't get me wrong-I think training and schooling activities are important for horses and dogs. This work establishes a foundation from which our stock-working partnership can proceed. A dog, for example, must understand that he must go around stock without "contact" until I ask him to come in. A horse (or mule) must understand leg and rein cues. Once this foundation-really a system of interspecies communication - is established, however, progress can only be made (I think) through "real" work.

In my experience, this is where time comes into play. Once Ernie, our youngest border collie, had a basic grasp of our communication system, I made several mistakes. First, I'd try to use him for real work - for moving sheep over long distances. I'd expect him to make good decisions, and I'd get frustrated when he didn't. Rather than take the time to help him understand what I was asking, I'd give up and use a more experienced dog. Not surprisingly (at least looking back), Ernie failed to progress. Second, I'd continue to try to school him with small groups of sheep, which just made him bored (and which led to more of the behavior I was trying to correct).

I've come to realize that I have taken a similar approach to riding my mule, Frisbee. Frisbee was started under saddle by a trainer friend of ours, JoDe Collins. We also started working her in harness, but never progressed beyond dragging things (logs, sleds, farm implements) to wheeled vehicles. In the intervening years, I didn't ride much (being busy with sheep-raising, mostly). Frisbee also had shown some fear of cattle (mostly at mule shows). Earlier this year, I needed another saddle animal at the Sierra Foothill Research and Extension Center (one of our SFREC horses has been lame since May). Frisbee was my only option. I'll admit to being a bit nervous about using her to work cattle, but she was the only choice.

The turning point in both examples was my realization that I needed to take time to build trust and communication while we were working! I started using Ernie for real work (mostly moving sheep and helping me put sheep through our corrals). Instead of getting frustrated with him, I started taking the time to work on problems as they occurred. Ernie's learning really accelerated when I started using him at SFREC to help me with cattle work. He's become a moderately talented dog with enormous heart and stamina-a wonderful partner.

Frisbee has progressed similarly. Rather than get frustrated by her "mule moments" (if you've ever worked with mules, you know what these are!), I started taking the time to help her get through them. If she balked at being ridden through the brush, I'd get off and lead her until she regained her confidence. Rather 
than worry too much about her being afraid of cattle, I simply started exposing her to cattle work in small doses. As her comfort level with the work and the place increased, I began asking her to do more and more. This last week, we gathered cows, herded them several miles up the road, and searched the brush for missing cattle. She handled everything I asked her to do.

Obviously, a strong foundation was critical in both cases. We had a system of communicating; what we lacked was experience and confidence (myself included). As Steve Cote, the author of Stockmanship ${ }^{3}$ writes, "Experience is knowledge, so this takes time." Both animals made huge strides when I stopped worrying about accomplishing a task by a certain time - as did I! When I finally accepted the fact that I truly was working on the animals' time- that the job couldn't be rushed (and that it usually went faster when I took my time) - we all gained knowledge and confidence.

The animals we are tending-sheep and cows-benefit from this approach as well; which brings me to my final point about time. At least for me, working with animals rarely goes perfectly - the problems, when I'm in the right frame of mind, are learning opportunities. Time for reflection is important.
Increasingly, I find myself seeking time to think about what worked and what didn't—and about what I would do differently. I also find myself taking time to ask others how they would handle similar situations. Learning, for all of us (humans and animals), it seems, takes time!

\section{References}

1. JacoBS, A. 2015. China Fences In Its Nomads, and an Ancient Life Withers. New York Times [Available at: http://www.nytimes.com/ 2015/07/12/world/asia/china-fences-in-its-nomads-and-an-ancientlife-withers.html?_r=0. Accessed 3 October 2015].

2. Kurlansky, M. 2010. Cod: a biography of the fish that changed the world. Penguin Books [294 p].

3. Cote, S. 2004. Stockmanship: a powerful tool for grazing lands management. USDA Natural Resources Conservation Service and Butte Soil and Water Conservation District. Available at: http:// www.grandin.com/behaviour/principles/SteveCote.book.html. 2004 [Accessed 3 October 2015].

Rangelands (37)6:237-240

doi: 10.1016/j.rala.2015.10.002

(C) 2015 The Society for Range Management 